Agro-Science Journal of Tropical Agriculture, Food, Environment and Extension Volume 14 Number 2 Mav 2015 nn 54 -_ 60

ISSN 1119-7455

\title{
BENEFITS AND CONSTRAINTS OF SHEA BUTTER PRODUCTION BY WOMEN IN NASARAWA STATE, NIGERIA
}

\author{
Okolo, C.C. ${ }^{1}$, Omoregbee, F.E. ${ }^{2}$ and Alufohai, G.O. ${ }^{2}$ \\ Nigerian Institute for Oil Palm Research, PMB 1030, Benin City, ${ }^{2}$ University of \\ Benin, Benin City \\ *Corresponding Author: e-mail: eddieokolo02@yahoo.com
}

\begin{abstract}
The study assessed women involvement in shea butter production activities in Nasarawa State, Nigeria. The specific objectives included the examination of the socio-economic characteristics of the women involved in shea butter production in Nasarawa, ascertaining the contribution of their involvement to their wellbeing and examining the constraints they face during the production activities. To achieve these objectives data on women shea butter production activities and benefits derived were collected from 97 respondents from the state using questionnaire and interview schedule. The data collected were analysed using descriptive (frequency distribution, mean) and inferential statistics (multiple regressions). The results revealed that the majority of the respondents were married, illiterate, young within the age bracket of 30-39 years and family size of more than 5. All of them belonged to farm associations. The major benefits the respondents believed they derived from their shea butter processing business included better feeding of household (46.9\%), more income (100\%) and improved child training (93.8\%). Two of the several major serious constraints the respondents faced in their production activities were hazards during fruit collection $($ mean $=2.54)$, inadequate inputs $(2.87)$. Multiple regression results revealed that age $(b=-$ $0.089)$, household size $(b=0.014)$, production experience $(b=-0.006)$, income $(b=0.210)$ and membership of cooperatives $(b=0.045)$ had a significant influence on the women level of involvement in shea butter production activities. From this study it can be concluded that shea butter production process in Nasarawa State, Nigeria is dominated by women with no formal education and their participation in the process was affected by or related to some socio-economic characteristics of the women. Also shea butter processing and sales is not a very lucrative business as income level is low. Nevertheless, women involvement was relatively high and income generated was of benefit to them.
\end{abstract}

Key Words: Women, Shea butter production, Benefits

\section{INTRODUCTION}

The shea tree (Vitellaria paradoxa Gaertn. F.) grows naturally in the wild in the Savannah belt of Africa, from Senegal in the west to Sudan in the east and into the foot hills of the Ethiopian highlands. The tree generally grows in the wild and its fruits, when ripe, fall off the tree and are collected, boiled or roasted to extract the nuts (Baba, 2008). In Nigeria today, the tree grows abundantly in Niger, Nassarawa, Kebbi, Kwara, Kogi, Oyo, Ondo, Kaduna, Adamawa, Zaria, Taraba, Borno and Sokoto States (Ogunsami, 2008). Niger State ranks first in terms of density and distribution of the tree (Okolo et al., 2012). Baba (2008) stated the benefits derived from the shea butter tree as follows - the pulp of the fruit is edible while the bark and root are used in traditional medicine.
Locally, it is used in childhood ointments for minor scrapes and cuts, and the shell of the nuts can be used to repel mosquitoes. Above all, the seed, when crushed, yields a vegetable oil that can be used in cooking, soap making, skin and hair care. This makes it a valuable trade commodity. Collecting the nuts and making butter have traditionally been women's work. Suleman (2008) observed that marketing the oil was giving women better opportunities, primarily through improved income. However, over $70 \%$ of the fruits produced is usually not collected or collected but not evacuated for processing leading to enormous waste (Suleman, 2008).

Shea tree activities in North Central States of Nigeria are sources of income to many people, especially women in the area but the 
level of income received is generally low when compared with the potentials. This is attributable to several factors. First the handling and processing methods adopted result in low quality of fruits and butter which fetch low prices and this reduces access to international markets. This situation is worsened by lack of awareness of the collectors and processors of superior handling and processing methods and equipment. Even in cases where they are aware, the cost of such equipment is generally beyond what they can afford as individual operators. Secondly, most of the collectors and operators are in small, scattered and remote areas which make access to markets difficult resulting in low prices. Thirdly, they lack bargaining power as they operate mostly as individuals. This frequently places them at the mercy of middlemen who usually go into the rural areas to purchase the nuts and butter. The collectors and processors who are mostly women therefore do not reap the expected benefits and recognition for their labour. However, to develop and derive more rewarding benefits from the shea tree, the socioeconomic analysis of its benefits becomes pertinent. This will be vital to policy makers as it will help them appreciate how different socioeconomic units of a population will affect existing policies and also help develop more user-friendly policies (Ajewole and Aiyeloja, 2004).

This study therefore examined the socio-economic characteristics of women involved in shea butter production in Nassarawa State of Nigeria, the benefits they derive from and the constraints they encounter in shea butter production to ascertain their contributions to the enhancement of their standard of living.

\section{MATERIALS AND METHODS}

The study was conducted in Nassarawa State Nigeria. The State is bounded in the north by Kaduna State, in the west by the Abuja Federal Capital Territory, in the south by Kogi and Benue States and in the east by Taraba and Plateau States. It lies within the coordinates $8^{0} .32^{\prime} \mathrm{N}$ and $8^{0} .18^{\prime} \mathrm{E}$ and has total land area of $27,117 \mathrm{sq} \mathrm{km}$ with human population of 2,040,097 (2006 census). It is within the derived Savannah region of Nigeria. Nasarawa State has agriculture as the mainstay of its economy with the production of varieties of cash crops throughout the year. Food crops produced in the state include yam, sweet potato, maize, etc. Few small holder plantations (1-10 ha) of oil palm are presently springing up in various parts of the state with the awareness that oil palm grows well in the area (NIFOR Report, 2010). The agroforestry parklands are dominated by trees such as Parkia biglobosa, Acacia senegalis,
Terminalia avicenniodes and Vitellaria paradoxa.

There also three senatorial zones in Nassarawa State Agricultural and Rural Development Project namely Western zone, Eastern zone and Southern zone. Each zone is made up of 10 extension blocks, each block has 8 extension circles, while the extension circle has 8 extension sub-circles and a total 1920 extension sub-circles in the entire State.

The population for this study includes all women shea butter producers in Nassarawa State of Nigeria. Sampling of respondents was done using the multi-stage sampling process. The sample was drawn from the ADP zones, Extension Blocks, Extension Circles and Extension Sub-circles. In the State, there are 20 registered women shea butter producers per block. There is therefore a total of 200 women shea butter producers that formed the sample frame in the State. Fifty percent $(50 \%)$ of the sample frame i.e. 100 women shea butter producers, were randomly selected for the study. However, only 97 copies of respondents' interview schedule were useful for analysis.

Data required to accomplish the objectives of the study were obtained from primary (questionnaire/interview schedule) and secondary sources. For the primary data a comprehensive open and close-ended questionnaire/interview schedule was developed and administered to the women shea butter farmers who constitute the target population of the study. The data collection instrument was validated by extension experts in the field before final administration to respondents. The instrument schedule was structured in such a way that it enabled the respondents provide information about their personal characteristics thus:

Sex: the respondents were required to indicate their sex. Male (coded 1), Female (coded 2) Age (years): Respondents were required to indicate their age group in the ranges provided: <20 (coded 1); $20-29$ (coded 2); 30 39 (coded 3$) ; 40$ - 49 (coded 4); 50 - 59 (coded 5); above 59 (coded 6).

Marital status: Respondents were required to indicate whether they are married or single. Married (coded 1), Single (coded 2), Widow (coded 3), Divorced (coded 4). Educational background: Respondents were required to indicate their level of educational attainment: No formal education (coded 1); Primary and Secondary (coded 2); NCE, TCII and ND (coded 3); First degree and HND (coded 4) and Post Graduate (coded 5).

Household size: Respondents were required to indicate the number of persons that are staying and feeding from the pot with them 
at the time of the interview in the range provided: $2-4($ coded 1$) ; 5-7($ coded 2$) ; 8-$ 10 (coded 3) and above 10 (coded 4).

Religion: Respondents were required to indicate their religion: African traditional religion (coded 1); Christianity (coded 2); Islam (coded 3) and others (specify) coded 4). Farming experience (years): Respondents were required to indicate their years of experience in shea butter production. The years to be provided are: $1-5($ coded 1$) ; 6-10($ coded 2$) ; 11-15$ (coded 3 ) and above 15 (coded 4) Estimated income per month from shea butter production: N10,000 and below (coded 1); N10,001 - 20,000 (coded 2); 20,001-30,000 (coded 3); 30,001 - 40,000 (coded 4); 40,001-50,000 (coded 5) and above 50,000 (coded 6). Membership of Association: Respondents were asked to indicate if they are members or non members of associations. If 'Yes', they should name the associations.

Frequency of extension contact: was measured based on weekly (coded 1); fortnightly (coded 2); monthly (coded 3); 3-6 months (coded 4), once a year (coded 5), not at all (coded 0$)$.

For the benefits associated with the shea butter processing activities, the respondents were required to indicate the various benefits they derive from the production of shea butter. Their responses were coded as Yes or No. A list of constraints sourced from previous studies and literature were made available to the respondents to identify those that apply to them in shea butter production. Their perceived constraints was measured on three scale item of $3=$ Very Serious, $2=$ Serious and $1=$ Not Serious. To determine which constraint was serious the perceived mean of 2.00 was used. Thus any constraint with a mean score of 2.00 and above was considered serious or otherwise if less than 2.00. This mean was determined as follows: $[3+2+1] / 3=2.00$

Secondary data were collected from literature and records of the ADPs.

Instrument for data collection was subjected to face and content validity: For face validity, assistance was solicited from experts in the field of rural sociology, rural health and agricultural extension. These experts were required to examine the question instrument and ensure that its contents were adequate in terms of measuring what it was designed to measure.

Reliability: This test proves reliability of the data collection instrument in terms of providing consistent results when administered to the same respondents on more than one occasion. The reliability of the measuring instrument was estimated using the test-retest technique. This was accomplished by administering the interview schedule to the same group of respondents at different times and the correlation between the two set of observations computed. A correlation value from 0.70 is usually considered acceptable.

Data collected were analyzed using descriptive statistics such as chart and frequency value (mean and standard deviations and percentages) and multiple regressions.

\section{RESULTS AND DISCUSSIONS}

Table.1 shows the socio-economic characteristics of the respondents. The result for age revealed that the majority of the shea butter producers in the study area were within the age bracket of 30-39 years, $60.8 \%$, within 40-49 years, $22.7 \%$ were between 40 - 49 years while $16.5 \%$ were less than 30 years. Majority of the respondents were below the age of 39 years $(77.3 \%)$. This shows that the producers were young and therefore probably indicates that shea butter production is an energy consuming activity that would be too stressful for older persons to engage in hence the predominance of young persons in the business. Reports by Ani et al, (2012) confirming this finding reported an average age of about 30 years for shea butter processors. However, studies by Daniel et al., (2005) revealed that shea butter producers were generally older with over $80 \%$ of their respondents being above 40 years old.

The results (Table 1) for the marital status of the respondents showed that all the respondents were married. The fact that all those involved in shea butter production were married is an indication that they engaged in it to cater for their families. The findings agree with the results of Daniel et al., (2005) who reported that most shea butter producers were married. An examination of the respondents' household size showed that about $35.1 \%$ had 5-7 persons living with them, also $35.1 \%$ had over 10 persons staying with them while $22.7 \%$ had $8-10$. The average household size was 7 indicating that the respondents had several persons staying with them. No doubt this large number of persons staying with them can assist them in the shea butter production operation. A household size of 7 was reported for shea butter producers in Benue state by Ani et al., (2012).

On educational status, the result also revealed that majority were not literate with a percentage of $85.6 \%$ having no formal education. About $11.3 \%$ attended primary school while $3.1 \%$ had NCE. This finding suggests that most shea butter producers in the study area were non-literate with very few having formal education. This low level of education may affect their adoption of new practices such as improved processing methods since it is asserted 
that being educated enables farmers to understand more easily the use of improved technologies

Almost all the respondents interviewed were Muslims with a percentage of $92.8 \%$ (Table 1). This suggests that the study area was largely a Muslim area. Another implication of this is that the religion is not against the adherents engaging in shea butter production. The results for the major occupation of the respondents revealed that most of them were farmers. The percentage was $99 \%$. Shea butter production is generally not a sole or major occupation among the respondents. This is because activities of shea butter production are carried out based on the availability of fruits which is seasonal.
In terms of experience in shea production the result of Table 1 showed that majority or $48.5 \%$ have been involved for $6-10$ years, $25.8 \%$ have been for 11 - 15 years while $11.3 \%$ have been involved for over 15 years. This shows that the respondents were quite experienced in shea butter production.

Only $1 \%$ of the respondents were not members of any farm association. About $49.5 \%$ of them belonged to Fadama association, 30.9\% belonged to Ena eko kpara chizhi group while $12.5 \%$ belonged to shea butter fruit association. Membership of farm organizations has the benefit of enabling farmers' access information and capital among others (Madukwe, 2005).

Table 1: Socio-economic Characteristics of Respondents

\begin{tabular}{|c|c|c|c|}
\hline Characteristics & Categories & $\mathbf{N}$ & Freq \% \\
\hline \multirow[t]{5}{*}{ Age (range) } & $<30$ & 16 & 16.5 \\
\hline & $30-39$ & 59 & 60.8 \\
\hline & $40-49$ & 22 & 22.7 \\
\hline & $50-59$ & - & - \\
\hline & Total & 97 & 100 \\
\hline \multirow[t]{5}{*}{ Marital status } & Single & - & - \\
\hline & Married & 97 & 100 \\
\hline & Widow & - & - \\
\hline & Divorced & - & - \\
\hline & Total & 97 & 100 \\
\hline \multirow[t]{5}{*}{ Household size range } & $4 \&$ below & 7 & 7.2 \\
\hline & $5-7$ & 34 & 35.1 \\
\hline & $8-10$ & 22 & 22.7 \\
\hline & $>10$ & 34 & 35.1 \\
\hline & Total & 97 & 100 \\
\hline \multirow[t]{5}{*}{ Educational level } & $\begin{array}{l}\text { No formal } \\
\text { education }\end{array}$ & 83 & 85.6 \\
\hline & Primary sch. & 11 & 11.3 \\
\hline & SSS & 3 & 3.1 \\
\hline & NCE & - & - \\
\hline & Total & 97 & 100 \\
\hline \multirow[t]{3}{*}{ Religion } & Christianity & 7 & 7.2 \\
\hline & Islam & 90 & 92.8 \\
\hline & Total & 97 & 100 \\
\hline \multirow[t]{4}{*}{ Major occupation } & Farming & 96 & 99 \\
\hline & Civil service & 1 & 1 \\
\hline & Trading & - & - \\
\hline & Total & 97 & 100 \\
\hline \multirow{5}{*}{ Production experience } & $1-5$ & 14 & 14.4 \\
\hline & $6-10$ & 47 & 48.5 \\
\hline & $11-15$ & 25 & 25.8 \\
\hline & $>15$ & 11 & 11.3 \\
\hline & Total & 97 & 100 \\
\hline Membership of Farm & Fadama association & 48 & 49.5 \\
\hline \multirow[t]{5}{*}{ Associations } & $\begin{array}{l}\text { Shea fruit } \\
\text { association }\end{array}$ & 12 & 12.4 \\
\hline & $\begin{array}{l}\text { Ena eko kpara } \\
\text { chizhi }\end{array}$ & 30 & 30.9 \\
\hline & Cooperatives & 6 & 6.2 \\
\hline & None & 1 & 1 \\
\hline & Total & 97 & 100 \\
\hline
\end{tabular}


Table 2: Perceived Benefits Derived from Shea Butter Production

\begin{tabular}{lcc}
\hline \multicolumn{1}{c}{ Benefits } & Freq & $\%$ \\
\hline & & \\
Better Feeding & 95 & 97.9 \\
& 97 & 100.0 \\
More Income & 91 & 93.8 \\
Improved Child Training & 34 & 35.1 \\
More Savings & 24 & 24.7 \\
Improve Knowledge/Skill of Production & 6 & 6.2 \\
More Output & 2 & 2.1 \\
Improved Usage & 15 & 15.5 \\
& & \\
More Customers & & \\
\hline
\end{tabular}

Table 2 shows the perceived benefits derived from shea butter production by the respondents in the study area. Based on the results it is seen that the major benefits the respondents believed they derived or are deriving from this business venture were better feeding of household (97.9\%), more income (100\%), training of children $(93.8 \%)$. Others include being able to save $(35.1 \%)$, improved knowledge and skill (24.7\%). The results suggest that the respondents are benefiting from shea butter production and this will encourage them to continue to engage in such a business venture. As the respondents realized more income from the venture they are in a better position to cater for their families, train their children and save more funds for future or emergency purposes. About $15.5 \%$ claimed their involvement in the business has helped them to know more customers which will further enhance their business. Shea butter producers generally engage in the business to provide their household with food, medicare and education as well as to purchase assets.

The regression results for factors affecting respondents' involvement in shea butter production are presented in Table 3 . The F value for the results, which is 39.92 , was significant at the $5 \%$ level meaning that the model is appropriate for the analysis and that the influence of the independent variables on the dependent variable (i.e. participation level) is significant. The adjusted coefficient of determination $\left(\mathrm{R}^{2}\right)$ square for the results is 0.744. What this means is that the independent variables in the model explained about $74.40 \%$ of variation in the dependent variable.

Based on the critical $t$ value at $5 \%$ level of significance, three of the explanatory variables were significant for the results namely age, household size and income. The results for age had a coefficient of $-0.089^{*}$. Since the result is negative it means that younger producers participate more in shea butter production activities than older producers. Younger persons have more energy to embark on more of the activities which can be quite tasking for example collection/picking of the fruits. Age of farmer has been reported to have a positive effect on their participation in agricultural project with younger farmers participating more in agricultural tasks (Nxumalo and Oladele, 2013).

The result for household size is positive $\left(b=0.139^{*}\right)$, which means that respondents with larger families participated more in the production activities than those with smaller families. This is possible since family members can assist or support them in the production activities. The result for production experience was negative $(b=-0.006)$, which means that respondents with longer experience in shea butter production participated more in the production activities than those with lesser experience. It is possible that those with longer experience have come to realize the benefit of participating more in the activities in order to get more output and income. Gani and Adeoti (2011) noted that the level of farmer participation in a production activity is an important determinant of output and income. 
Table 3: Factors Affecting Respondents' Involvement in Shea Butter Production in Nasarawa State.

\begin{tabular}{lll}
\hline Independent variables & b & t \\
\hline Constant & 3.973 & 1.708 \\
Age & $-0.089^{*}$ & -2.282 \\
Household size & $0.139^{*}$ & 2.623 \\
Educational level & 0.273 & 0.919 \\
Production experience & -0.006 & -0.141 \\
Income & $0.210^{*}$ & 3.134 \\
Membership of cooperative & 0.045 & 0.041 \\
Contact with extension agents & 0.375 & 1.244 \\
Perceived benefits & 0.104 & 0.439 \\
\hline
\end{tabular}

$*$ Significant at the $5 \%$ level (critical $\mathrm{t}=1.96)$

Table 4: Constraints Faced by Women in Shea Butter Production

\begin{tabular}{lll}
\hline Constraints & Mean & SD \\
\hline & $2.54^{*}$ & .54 \\
Hazards faced during fruit collection & $2.98^{*}$ & 20 \\
Poor access to investment c & $2.90^{*}$ & .34 \\
redit & 2.87 & 34 \\
Poor production skills & 0.68 & .22 \\
Inadequate inputs (improved processing technology) & 0.83 & .34 \\
Low income level & $2.97^{*}$ & .17 \\
Lack of Government interest & $2.76^{*}$ & 45 \\
Low consumer patronage & $2.55^{*}$ & .54 \\
Poor market price & $2.25^{*}$ & 72 \\
Low level of education & $2.07^{*}$ & 74 \\
Lack of knowledge about storage & 1.20 & 47 \\
Irregular visit by Extension Agents Discouragement from & & \\
husband/religion & &
\end{tabular}

Income of the respondents was positively related to their level of participation since the coefficient is positive $\left(b=0.210^{*}\right)$. The positive sign means that respondents with higher income participated more in the production activities than those with lesser income. This is possible since with more money respondents can afford to purchase or hire inputs required for the production of shea butter. The results agree with the report of Nxumalo and Oladele (2013) who found a positive and significant relationship between income of farmers and their level of involvement in agricultural project. Similar relationship between income and participation in farm project was reported by Damiss et al., (2007). The relationship between respondents membership of cooperative and participation in shea butter production was positive $(b=0.045)$. The positive sign or relationship means that respondents who belonged to cooperatives participated more in shea butter production activities. This suggests that belonging to a cooperative encourages producers to participate more in the production activities.

The findings of the study revealed (Table 4) that the respondents faced serious constraints especially hazards during fruit collection with a mean of 2.54 , poor access to investment credit (mean $=2.98$ ), inadequate production skills (2.90), inadequate inputs (2.87), low consumer patronage (2.97) poor market price (2.76) and poor educational level (2.55) and limited knowledge about storage methods (2.25), irregular visit by extension agents (2.07).

The fruit collection process is usually a very stressful activity. Because the fruits are collected from the ground the women have to constantly bend over during the entire collection duration and hand-pick them. Lack of capital does not allow the women to purchase improved processing technology. Moreover, they claimed that the technology was not avaslable to them and, that area of available, they do not know how to operate it. They lamented that the price charged for the shea butter in the market was not encouraging and this perpetually keeps them in poverty.

Inaccessibility of improved processing methods, high cost of equipment and lack of access to credit were identified as important constraints facing shea butter processors by Issahaku et al., (2011). Holtzman (2004) equally noted that finance constitute a major impediment to improvement in shea butter production. According to Esinam (2010), shea butter producers mentioned lack of capital, inadequate equipment, inadequate water facilities, high cost of fuel wood and production difficulties due to the use of largely manual production tools as the major constraints of processing activities. Furthermore, the marketing constraints of the 
Okolo, C.C., Omoregbee, F.E. and Alufohai, G.O.

women, the author noted, also included inadequate buyers, fluctuation in market prices, high cost of transportation among others. From this study it can be concluded that shea butter production process is dominated by women with no formal education and their participation in the process was affected by or related to some socioeconomic characteristics of the women. Also shea butter processing and sales is not a very lucrative business as income level is low. Nevertheless, women involvement was relatively high and income generated was of benefit to them.

\section{REFERENCES}

Ajewole, O.I. and Aiyejola, A.A. (2004). SocioEconomic Analysis of Benefits of Ibadan Urban Forest Reserves. Journal of Tropical Forest Resources, 20(1): 95 $-105$

Ani, D.P., Aondona, G and Soom, A. (2012). Economic Analysis of Shea Butter Plant in Ukum Local Government, Benue State, Nigeria. AmericanEurasian Journal of Agronomy 5 (1): 10-18, 2012

Baba, K.M. (2008). Strategies for Sensitizing, Mobilizing and Organizing Shea nut Collectors and Processors in Niger State Cooperative societies. roceedings of Stakeholders and Sensitization Workshop on Potentials and onstraints on Shea Production in Niger State. Minna p5

Damiss, M.A., Samndi, R. and Yohanna, M. (2007). Women Participation in Agricultural Production: A Probit Analysis. .J of Applied Sciences, 7: 412-416.

Daniel, A., Olafimihan, O., Kwaya E, and Odejide, O. (2005). Shea nut processing. Raw Material update. A Biannual publication of Raw Materials Research and Development Council Vol. 5. No. 2.

Esinam, P.F. (2010). Financing the Production and Marketing of Shea Butter in Tamale Metropolis of Ghana. MScience. Thesis, Department of Planning, Faculty of Planning and Land Economy, College of Architecture and Planning Kwame Nkrumah University of Science and Technology p68

Gani, B.S. and Adeoti, A.I. (2011). Analysis of Market Participation and Rural Poverty among Farmers in Northern Part of Taraba State, Nigeria. $J$ of Economics, 2(1): 23-36
Holtzman, J. (2004). The Shea Butter Value Chain: Study Synthesis and Recommendation for WATH. WATH Technical Report No. 1, Dakar, WATH

Issahaku, H., Al-hassan, R. and D.B. Sarpong (2011). An Analysis of Allocative Efficiency of Shea Butter Processing Methods in the Northern Region of Ghana. Journal of Development and Agricultural Economics. Vol. 3(4), 165173

Madukwe, M.C. (2005). Agricultural Extension Administration. In: Adedoyin, S.F. (ed). Agricultural Extension in Nigeria, Agricultural Extension Society of Nigeria, Ilorin. PP. 182185.

Mohammed, A.A. (2002). Women Participation in Agriculture. The American University Social Research Monograph. 4pp

NIFOR (2010). Institute Report on Wamba Substation. 6pp.

Nxumalo, K. K. S. and Oladele, O. I. (2013). actors Affecting Farmers' Participation in Agricultural Programme in Zululand District, Kwazulu Natal Province, outh Africa. Journal of Social Science, 4(1): 83-88

Ogunsami, T. (2008). Shea nut Potentials in Niger State and Its economic Value in Developing the State. Proceedings of Stakeholders and Sensitization Workshop on Potentials and Constraints on Shea nut production in Niger State. Minna, 1-2

Okolo, E.C., Enaberue, L.O, Okwuagwu,C.O., Yusuf,A and Okoye, M.N. (2012) Density and Phynotypic Variation of Vitellaria paradoxa Gaertn. F. in Agroforestry Parklands of Nigerian Guinea Savannah. Ife J Agric. Vol `12, $35-43$.

Suleiman, M.A.I. (2008). Assessment of Potentials for Shea Nuts in Selected LGAs of Niger State. Proceedings of Stakeholders and Sensitization Workshop on Potentials and Constraints on Shea Nut Production in Niger State. October 2008 